\title{
Genetic transformation of eucalyptus
}

\author{
V. Girijashankar
}

Published online: 12 February 2011

(C) Prof. H.S. Srivastava Foundation for Science and Society 2011

\begin{abstract}
Eucalyptus is the second most widely planted multipurpose woody tree species in the world. It is a commercially important hardwood tree for paper and wood industries. In the past two decades, various research groups reported different genetic transformation protocols and attempts towards development of transgenic eucalyptus. Much of the work related to its genetic improvement through transgenic technology has been undertaken by private companies that keep the data confidential, patented and often share only a part of the scientific information as publications. The important areas which received scientific attention are wood quantity, quality, stress resistance and rootability. The present review deals with scientific advancements and insights made through the development of transgenic eucalyptus.
\end{abstract}

Keywords Genetic transformation · Transgenic eucalyptus · Transgene escape

\section{Introduction}

Eucalyptus are important hard wood trees, originated in Australia and belongs to the family Myrtaceae. The estimated plantation area covered by eucalyptus is 20 million hectares worldwide (GIT Forestry 2008). The genus Eucalyptus comprises of more than 700 species and hybrids, some of which bear their economic importance as a source of paper pulp, wood, timber and essential oils

\footnotetext{
V. Girijashankar $(\bowtie)$

Center for Biotechnology, Institute for Science and Technology, Jawaharlal Nehru Technological University (JNTU),

Kukatpally,

Hyderabad 500072 Andhra Pradesh, India

e-mail: vgirija_shank@yahoo.com
}

(Eldridge et al. 1994). The ever increasing demand for wood, timber and shelter poses a great threat to the natural forest resources. Eucalyptus being a hardwood tree produces shorter fibers than softwoods like pines. Short fibers of this genus make it more reliable for use in paper and furniture industries due to its desirable surface characteristics, smoothness, brightness and low tensile strength. Further, eucalyptus plays an important role in plywood, particle board making and furniture industries due to its tall and straight timber which is of medium to high density. Fast growing and high yielding eucalyptus plantations with their short rotation period along with adaptation to a wide range of environments offer enormous scope as an alternative to meet the growing wood demands of the world as well as to save the natural forests from deforestation.

\section{Need for genetic transformation of eucalyptus}

The genus Eucalyptus is gaining economic significance worldwide for its species are largely exploited as one of the main sources of biomass. Among the 700 species and hybrids, E. grandis is the most widely cultivated species in subtropical and warm temperate regions. E. camaldulensis is a common species of arid and semi-arid regions while $E$. globulus grows predominately in temperate climates free of severe frosts. The species E. urophylla is highly productive whereas E. nitens is an important cold adaptable species (Teulieres and Marque 2007).

Genetic improvement of plants through transgenic technology enables introduction of specific traits of interest into a desirable genotype. In conventional breeding approach, the traits of interest have to reside within the species of the same genera. On the other hand, genetic 
modification based transgene technology enables the transfer of selected genes across genera and kingdoms. Further, the transfer of selected genes in a single generation through transgenic technology is especially important for eucalyptus, as its improvement by conventional breeding approach is limited by long breeding cycles, high levels of heterozygosity and incompatibility barriers (Machado et al. 1997). Except in few occasions such as the use of SNP markers for $\mathrm{ccr}$ gene which determine reduced microfibril angle (MFA) in E. nitens (Thumma et al. 2005), the progress made by molecular breeding towards germplasm improvement of eucalyptus through genomics approach is minor, so far. Contrary to woody plants, food crops (example: Sorghum bicolor) and commercial field crops receive much research focus in the domain of genomics and genetic transformation (Girijashankar and Swathisree 2009). There are many scientific reports on successful introduction of foreign genes into food crops. Unfortunately, forest trees still remain a challenge to transgenic technology.

Moreover, transgenesis provides a powerful complementary approach enabling functional analysis of gene at specific stages of tree growth. Genetic transformation as a tool to understand plant development has been widely used in annual plant species. With the advent of new molecular and in vitro techniques, transgenic technology has become increasingly available to study the basic question of plant biology in woody perennials, such as eucalyptus (Spokevicius et al. 2007a; Vain 2006).

\section{Genetic transformation of eucalyptus}

The pre-requisites for plant transformation approach are: a) gene construct carrying the polynucleotide(s) coding for trait(s) of interest, b) reliable method to transform the explants, c) selection of plant tissue harboring transgene and d) an efficient plant regeneration protocol. Though the above steps were successfully carried by various research groups across the world, genetic transformation of eucalyptus is at its infancy. Commercial utilization of transgenic eucalyptus is at its initial stage due to hurdles such as high costs of generating transgenic plants, patents, lack of information on transgene escape in forestry tree species, variation in transgene expression patterns across age and tissues etc.

\section{Traits of interest and their related genes}

Earlier studies, during the last two decades, towards genetic enhancement of tree species have been mainly focused on cellulose modification or biosynthesis (Shani et al. 2004), increase in biomass and modification of lignin content.
Other studies of importance include imparting tolerance to biotic (pests and diseases) and abiotic stresses (drought, cold and salinity) followed by enhanced phytoremediation, sterility and rootability (Teulieres et al. 1994; Quoirin and Quisen 2006).

\section{Enhancing wood quantity and quality}

Wood quality and biomass enhancement are of major concern for wood based industries. Quality of wood is determined by the strength and flexibility of the wood and lignin content that dictates its suitability for paper making and timber purpose. Secondary cell wall consists of cellulose, lignin and other cellulose polysaccharides representing $90 \%$ of the wood dry weight that provides support for the cell. Further, cell wall proteins and other compounds also make their contributions in the cell wall structure and function (Savidge 2000). Changes in the composition of these elements qualitatively and quantitatively can lead to changes in cell wall properties and are responsible for variations in wood properties observed within and across tree species (Spokevicius et al. 2007a).

\section{Biomass enhancement}

Biomass enhancement can be achieved through manipulation of cellulose synthetase genes or precursors of cellulose biosynthesis. Lignin content and cellulose fiber angle are inversely related to cellulose content. $C b d$ and cell encodes for cellulose binding domain and endo-1,4- $\beta$ glucanase, respectively. These are the two genes of interest aimed to increase cellulose content. Cellulose binding domains are shown to modulate the elongation of plant cells in vitro while the gene cell is implicated in cell wall enlargement. Native endo-glucanases are involved in cell elongation through the hydrolysis of cellulose-xyloglucan links allowing the cellulose chains to move freely. Over expression of these genes in plants can induce elongation of cells more rapidly which in turn results in faster growth and development of transgenic eucalyptus trees. Shani et al. (2003, 2004) developed 25 transgenic eucalyptus lines carrying $\mathrm{Cbd}$ and Arabidopsis thaliana endo-glucanase cell fused to different promoters. They introduced these genes into E. camaldulensis, E. grandis and its hybrids.

Other attempts towards biomass enhancement are at preliminary stage. The expression of E. camaldulensis transcription factor $(E c H B 1)$ genes related to xylem development is examined by Sonoda et al. (2009). The gene $E c H B 1$, encoding for a HD-ZIP class II protein driven by CaMV $35 \mathrm{~S}$ promoter, has been introduced into tobacco. These transgenic plants showed greater fiber length $(20 \%)$ and increased plant height $(50 \%)$ when compared to the 
wild type. The growth of leaves, roots and stem is significantly enhanced in transgenic plants which also showed a lower acid soluble lignin and hemicellulose content than wild-type. Their results indicated that metabolic flexibility might be involved in these improvements to xylem cell wall biosynthesis in addition to providing a growth advantage such modification might confer long term structural integrity to the woody perennials. The gene $E c H B 1$ should be the next level of transgenes, after $C b d$ and cell, working its way towards enhancing eucalyptus biomass.

\section{Micro fibrillar angle (MFA)}

An important wood quality trait that determines the fiber and wood stiffness/elasticity is the microfibrillar orientation in the secondary fiber cell walls which is simply referred to as micro fibril angle (MFA) (Long et al. 2000). Lesser the cellulose MFA, higher is the mechanical strength of fibers and vice versa. So far, various attempts were made to study the genes involved in MFA determination. However, no single complete transgenic eucalyptus plant is developed in this direction.

The transformation studies conducted by Spokevicius et al. $(2007 \mathrm{a}, \mathrm{b})$ revealed that $E$. grandis $\beta$-tubulin gene (EgrTUB 1) is involved in determining the orientation of cellulose microfibrils in plant secondary fiber cell walls. This finding is based on RNA expression studies in mature trees, where they identified and isolated EgrTUB1 as a candidate gene associated with wood fiber formation, and by the analysis of somatically derived transgenic wood sectors in E. globulus trees. They indicated that cellulose MFA is correlated with EgrTUB1 expression, and that MFA is significantly altered as a consequence of stable transformation with EgrTUB1.

Other genes of interest which are found to influence the microfibrillar orientation in the cellulose secondary cell wall are FRA1 coding for a kinesin-like protein with an Nterminal microtubule binding motor domain and $C C R$ gene coding for cinnamoyl CoA reductase, a key enzyme in lignin biosynthetic pathway. In Arabidopsis, inflorescence stems, FRA1 is known to influence the mechanical strength of fibers and is proposed to be involved in microtubule control as well as cellulose microfibrillar order (Zhong et al. 2002).

$C C R$ allelic variation has been well correlated with variation in MFA in E. nitens using association mapping (Thumma et al. 2005). Genetic transformation of eucalyptus with FRAI and CCR sequences can help in increasing the mechanical strength of fibers by reducing the cellulose MFA. Recently, Fasciclin-like arabinogalactan (FLAs) proteins were identified to be specialized in stem biomechanics and cell wall architecture in eucalyptus. Using phylogenetic, transcript abundance and promoter-GUS fusion analyses, MacMillan et al. (2010) recently identified a conserved subset of single FAS domain belonging to group of FLAs in eucalyptus stem cells undergoing secondary cell wall deposition. Thus, Fasciclin-like arabinogalactan sequences can play a major role in generating transgenic eucalyptus, especially for stem biomechanics.

\section{Altering lignin pathway}

Lignin is a heterogeneous phenolic polymer that provides rigidity to cell walls; confers water permeability to xylem vessels and forms a physio-chemical barrier against microbial attack (Monties 1989). But high amount of lignin is undesirable for paper manufacturing because the residual lignin in the wood fibers results in discoloration and decrease the brightness of the pulp (Chiang et al. 1988). Hence, it is mandatory for paper industries to remove lignin during pulping process without damaging the cellulose polysaccharides, a process that requires huge amount of sodium hydroxide and sodium sulphide along with other bleaching agents that eventually pose a threat to the environment as well as decrease the cellulose fiber strength due to their chemical action. A genetic transformation approach to produce transgenic eucalyptus trees with reduced lignin content or by modification of the lignin composition could make its removal easy with reduced usage of chemicals that might prove helpful to overcome the hurdles in quality paper-making. The monolignols, $p$-coumaryl, coniferyl and sinapyl alcohols give rise to the lignin polymer units such as $p$-hydroxyphenyl $(H)$, guaiacyl $(G)$, and syringyl (S) respectively that are linked by a series of ether and carbon-carbon linkages (Higuchi 1990; Lapierre et al. 1999). Lignin rich in $S$ units are more desirable than lignin rich in $G$ units as the $\beta$-O-4-linkages of $\mathrm{S}$ units are more susceptible to chemical delignification process than the relatively stronger carbon-carbon bonds of G-units (Chiang et al. 1988; Lapierre et al. 1999).

Regulatory sequences and genes coding for different enzymes of monolignol biosynthetic pathways are of more interest to genetic engineers. The enzymes of monolignol biosynthetic pathways comprising of cinnamyl alcohol dehydrogenase (CAD); coumarate 3hydroxylase $(\mathrm{C} 3 \mathrm{H})$; cinnamate 4-hydroxylase $(\mathrm{C} 4 \mathrm{H})$; coumaroyl-coenzyme A 3-hydroxylase (CCoA3H); caffeoyl-coenzyme A $O$-methyltransferase (CCoAOMT); cinnamoyl-coenzyme A reductase (CCR); caffeic acid $O$ methyltransferase (COMT); ferulic acid 5-hydroxylase (F5H); 4-coumarate:coenzyme A ligase (4CL); phenylalanine ammonia-lyase (PAL). Further the transcription factors/regulatory sequences such as myb and lim genes are used in transformation works. 
Chen et al. (2001) from Taiwan's Forestry Research Institute, successfully developed two transgenic E. camaldulensis events harboring aspen $\mathrm{C} 4 \mathrm{H}$ (cinnamate-4-hydroxylase) gene both in sense and anti-sense orientation. With an aim to alter the quantity and quality of lignin in transgenic plants, this team used in vitro raised plantlet leaves as explants and co-cultivated them with Agrobacterium tumefaciens containing binary construct carrying Populus tremuloides $+/-C 4 H$, nptII and uidA genes. Characterization of these two lines has been in progress because of which further details are not well known. In an another investigation, the genome of hybrid eucalyptus ( $E$. grandis $\times E$. urophylla) is transformed with anti-sense DNA sequence of cad enzyme (cinnamyl alcohol dehydrogenase) from E. gunni using Agrobacterium-mediated transformation of young seedling leaves (Tournier et al. 2003). Among the 120 transformants which have been recovered, $58 \%$ showed significant inhibition of cad activity. Preliminary data on lignin from two promising lines growing under glass house conditions revealed $26 \%$ and $22 \%$ residual CAD activity which seems encouraging. Using the same construct from E. gunni, Valerio et al. (2003) transformed E. camaldulensis. A total of 44 transgenic lines were generated of which $32 \%$ exhibited upto $83 \%$ reduction in cad activity. However, it had been reported that after 10 months of growth in glasshouse, none of the five transgenic lines tested, showed any change in lignin profiles or cad activity when compared to untransformed control plants (quantity, composition and pulp yield).

So far in lignin modifying efforts, two different transcription factors have been used in eucalyptus transformation works. Anti-sense construct of tobacco transcription factor Ntlim 1 that specifically binds to phenylalanine ammonia lyase (PAL box sequence) and inhibit transcription of few phenylpropanoid pathway genes such as phenylalanine ammonia lyase (PAL), hydroxycinnamateCoA ligase $(4 C L)$ and cinnamyl alcohol dehydrogenase $(C A D)$, has been introduced into the genome of $E$. camaldulensis. As expected, the transgenic events showed down regulation of lignin biosynthetic pathway genes and few of the transgenic events showed reduced lignin content by $20-29 \%$ in cell wall residues of stem xylem tissues (Kawaoka et al. 2003, 2006). Reduction of lignin content in E. camaldulensis by the suppression of gene expression using LIM domain transcription factor, Ecliml, isolated from the E. camaldulensis is reported by Kawaoka et al. (2006). LIM domain transcription factor is involved in lignin biosynthesis that specifically binds to cis-acting element of the PAL box sequence. These transgenic eucalyptus plants grown in the greenhouse showed decreased expression of several lignin biosynthesis genes such as $P A L, C 4 H$ and 4hydroxycinnamate CoA ligase $(4 C L)$.
Altering fertility

According to the US forest biotechnology company, ArborGen, the greenhouse tests with transgenic tobacco as well as with an early flowering model of Eucalyptus (E. occidentalis), showed that the barnase gene demonstrated $100 \%$ efficacy in preventing viable pollen formation (ISIS 2010). Among the developing flower buds from (field grown) transgenic Eucalyptus lines containing barnase gene, $90 \%$ of lines showed complete pollen ablation. Recent observations from the replicated field study conducted in Alabama state it is confirmed that cold tolerant trees allowed to flower did not produce any viable pollen (US BRS permit, BRS \# 06-325-111r-a1).

\section{Biotic stress resistance}

Insect resistance/tolerance in plants can be imparted by introducing cry genes coding for crystalline toxin proteins from Bacillus thuringiensis. Transgenic E. camaldulensis plants conferring resistance to Chrysomelid beetles and tolerance to the herbicide ammonium glufosinate are produced by Harcourt et al. (2000) via transformation of 2-week-old seedlings with insecticidal cry $3 A$ and bar genes, respectively. Insect and herbicide resistant transgenic eucalyptus are likely to provide better pest and weed control options in plantations, particularly during the early vulnerable establishment phase, provided that any adverse ecological impacts of releasing transgenic plants into the environment can be assessed and minimized. Shao et al. (2002) developed transgenic E. urophylla events showing an increased resistance by $35 \%$ against the bacterial wilt disease caused by the pathogen, Pseudomonas solanacearum.

\section{Abiotic stress tolerance}

Genetic improvement of eucalyptus for tolerance to abiotic stresses including salinity, acidity, drought and cold were attempted. In order to impart salinity tolerance, YamadaWatanabe et al. (2003) introduced $\operatorname{codA}$ gene from Arthrobacter globiformis into eucalyptus. This transgene codes for choline oxidase, an enzyme that converts choline to glycine betaine. These transgenic lines exhibited tolerance to salinity, high and low temperatures. Japan's Oiji paper industries, with an objective to improve inorganic phosphate uptake by eucalyptus growing in acidic soils attempted the introduction of a mitochondrial citrate synthetase gene into the hybrids of $E$. grandis $\times E$. urophylla. Compared to control plants, in the transgenic events, a five-fold increase in enzymatic activity is reported 
which in turn lead to a similar growth with colloidal aluminum phosphate compared to sodium phosphate (Kawasu et al. 2003). These transgenic events showed enhanced phosphorus uptake even in acidic soils.

Another experiment that involved the over expression of dreb 1 gene, a transcription factor which regulates gene expression during drought conditions, is introduced into eucalyptus genome. The transgenic plants showed improved tolerance to drought as well as saline conditions (Kondo et al. 2003; Ishige et al. 2004).

In a recent report by Navarro et al. (2010), two coldinduced transcription factors that specifically bind to Cbinding factor genes namely $E g u C B F 1 \mathrm{a} / \mathrm{b}$ are isolated from E. gunni and constitutively over-expressed in a coldsensitive eucalyptus hybrids. In addition to the expected improvement on freezing tolerance, the resulting transgenic lines exhibited a decrease in stomatal density and over-accumulation of anthocyanins. Further, these transgenic events showed wax deposition on cuticle, reduced leaf area, decreased cell size, retarded growth and better water retention capacity under cold stress when compared to control non transgenic plants. This study not only revealed the $\mathrm{CBF}$ transcription factors role (first signs of adaptive mechanisms controlled by CBR related genes) but also generated cold tolerance eucalyptus transgenic lines. Interestingly, this research opened up new avenues for genetic improvement on eucalyptus for freeze tolerance.

\section{Improved rooting}

Poor rooting capability of several eucalyptus commercial clones having desirable traits is a well known rate limiting factor for their success in clonal propagation. In an attempt to improve rooting of in vitro propagated clones of $E$. grandis, E. dunnii and E. nitens, Macrae and Van Staden (1993) used hairy-root inducing Agrobacterium rhizogenes strains and reported improvement in rootability of the selected clones. The transformed shoots grew into root cultures in hormone-free liquid medium with enhanced growth rate, extensive lateral branching but lacks geotropism. However, the transformed plantlets on transfer to soil did not display the typical hairy root phenotype but they grew normally with good secondary root development along with a firm root plug. The potential use of $A$. rhizogenes strains towards improving the rootability of in vitro propagated explants from hard-to-root genotypes of eucalyptus is well exploited.

Later, Machado et al. (1997) in their studies related to improved rooting with Agrobacterium strain on E. grandis $\times$ E. urophylla hybrids observed variations in susceptibility of eucalyptus genotypes. They reported difference in root growth rate and extent of lateral branching in roots which varied with Agrobacterium strain and eucalyptus genotypes being used.

\section{Promoters, reporter genes and selection markers}

\section{Promoters}

The efficient expression of transgene in the host system, generally dictates the success of any genetic transformation study. Selection of a suitable promoter that initiates high levels of expression is, therefore, important. A plant promoter is a regulatory sequence capable of initiating the transcription of the polynucleotide in the plant cells. The gene promoter and termination sequences may be endogenous to the target host plant or exogenous derived from other species capable of functioning in the target plant. The class of non-constitutive promoters include tissue specific, tissue preferred, cell type specific and inducible promoters that directs transcription initiation in specific tissue such as leaves, stem, roots, seeds, cell types, organs and stress inducible, respectively. A constitutive promoter is active under most environmental conditions and in almost all plant parts. The frequently used promoter for wood transformation studies is CaMV 35S. It has been found to produce larger phenotypic changes when compared to wood-specific promoters (Yahiaoui et al. 1998). This constitutive promoter is also the most extensively used regulatory sequence in genetic transformation studies of eucalyptus (Table 1).

Genes that are expected to express in certain plant parts of interest or under stress conditions, when driven by the strong constitutive promoter $\mathrm{CaMV} 35 \mathrm{~S}$ can lead to undesirable changes in transgenic eucalyptus. Dibax et al. (2010) reported growth reduction in leaves and roots of few transgenic $E$. saligna plants that expressed the abiotic stress tolerance P5CS gene under CaMV 35S promoter. This was attributed to the excess free proline accumulation that is desired to be expressed only under cold stress conditions. In E. camaldulensis, Kawaoka et al. (2006) reported abnormal phenotypic changes in the line LG12 which showed a maximum reduction of lignin content (upto 29\%), in which the transcript level of anti-sense Eclim1 under the control of CaMV 35S is over expressed. Ecliml is one of the key transcription factors involved in lignin biosynthesis. The transgenic LG12 plants grew abnormally and exhibited altered leaf shapes, dropping upper leaves etc.

Recently, Navarro et al. (2010) reported that (in comparison with the control plants) the most altered transgenic line (EguCBF1a-OE A1 line) constitutively over expressing Crepeat binding factor under the control of CaMV $35 \mathrm{~S}$ promoter exhibited reduced growth. These works on transgenic eucalyptus caution the researchers on the 


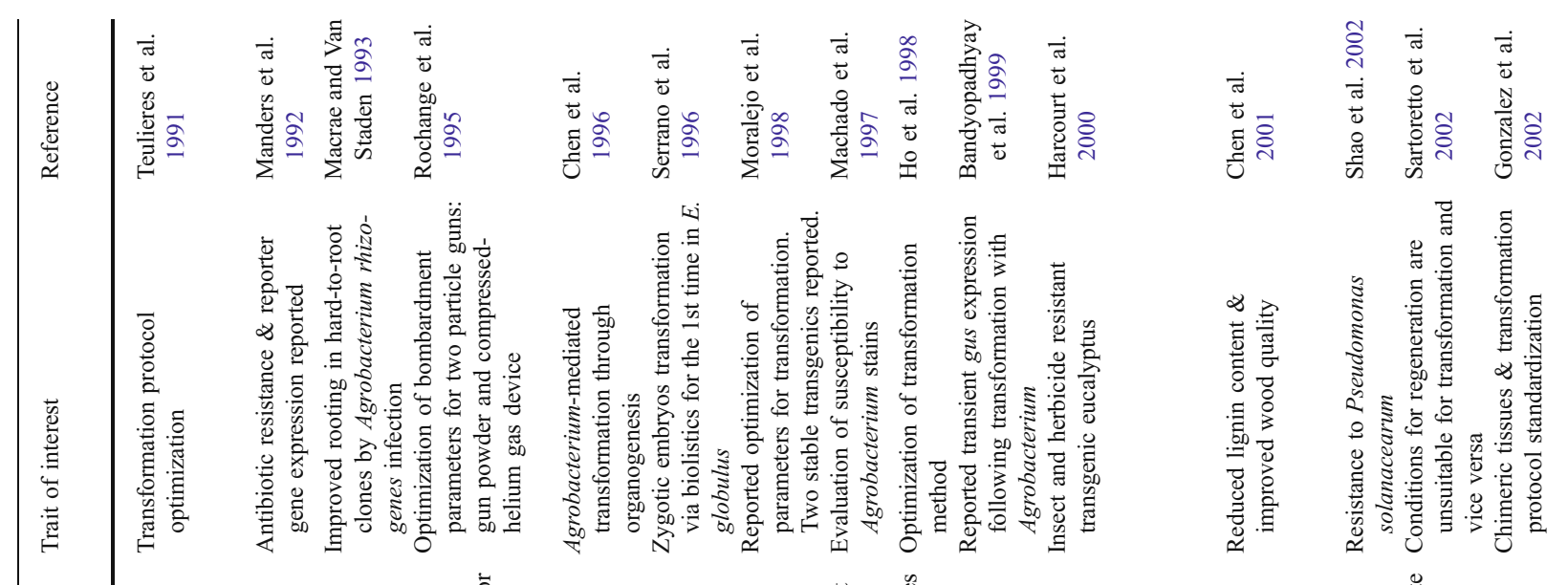

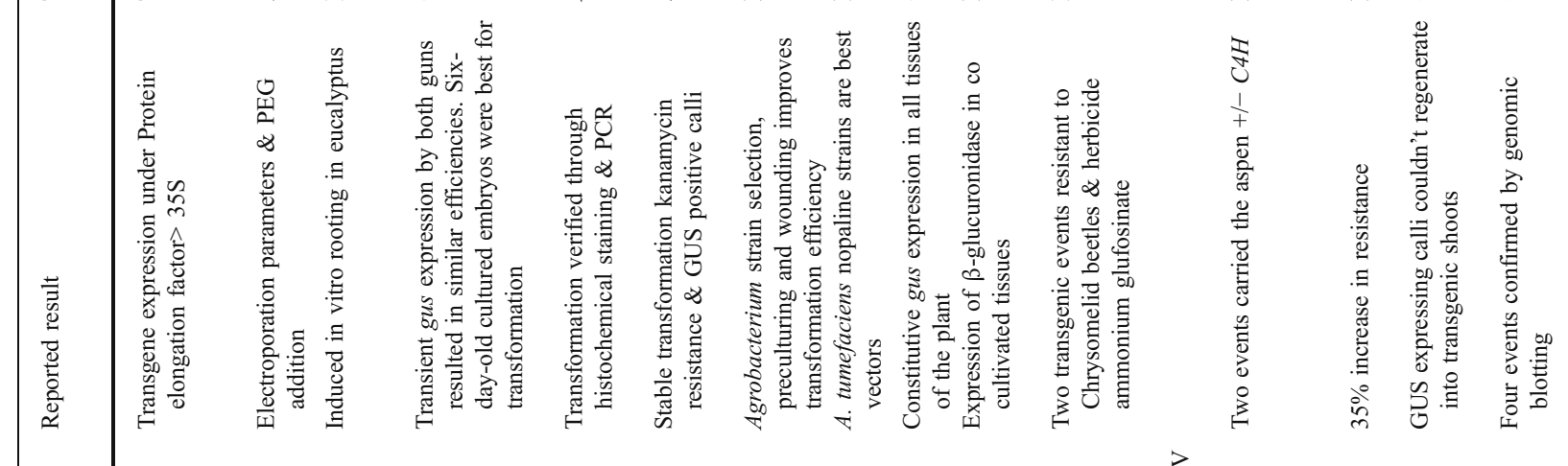

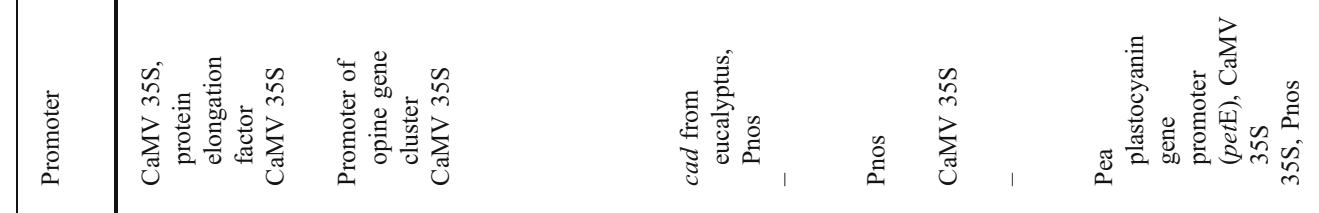

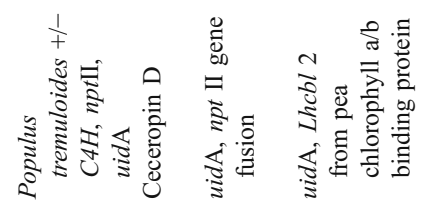

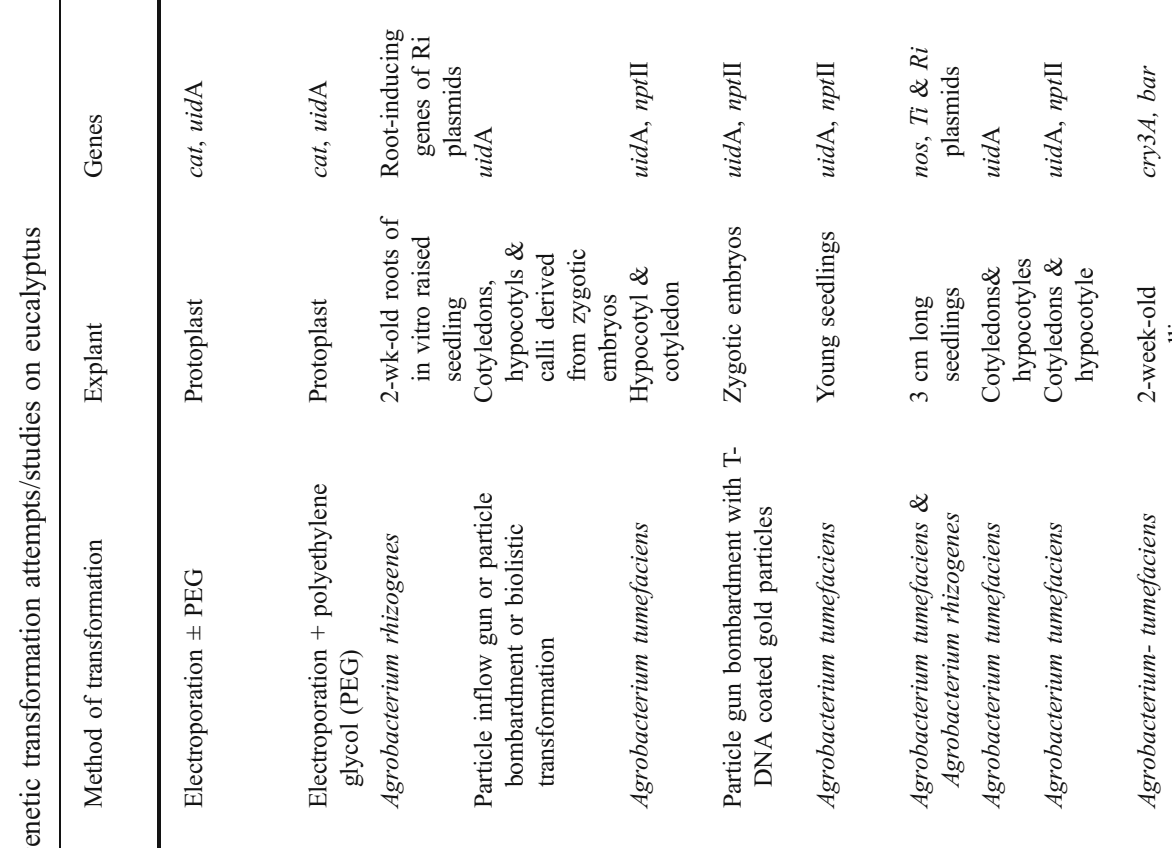

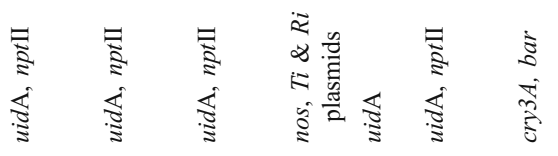

$\frac{0}{0} \sum_{0}^{\infty} \sum_{0}^{\infty}$

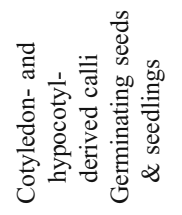

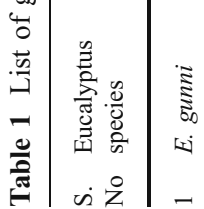
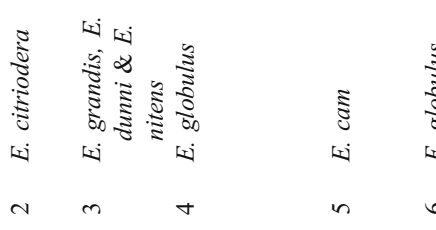

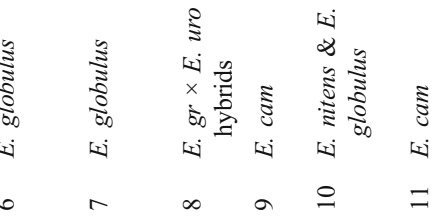

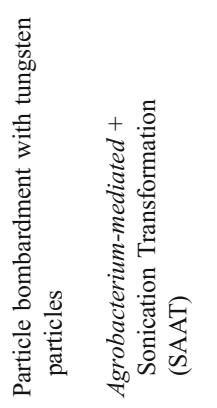




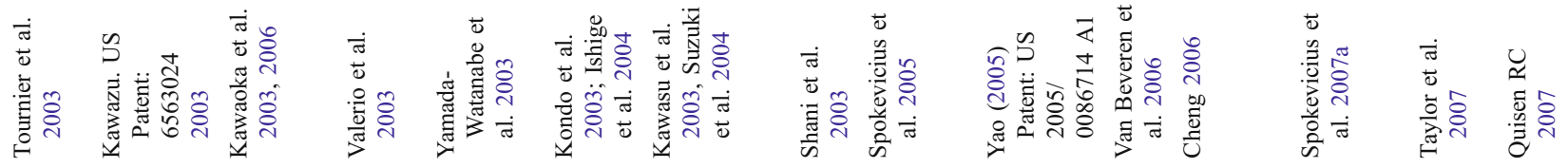

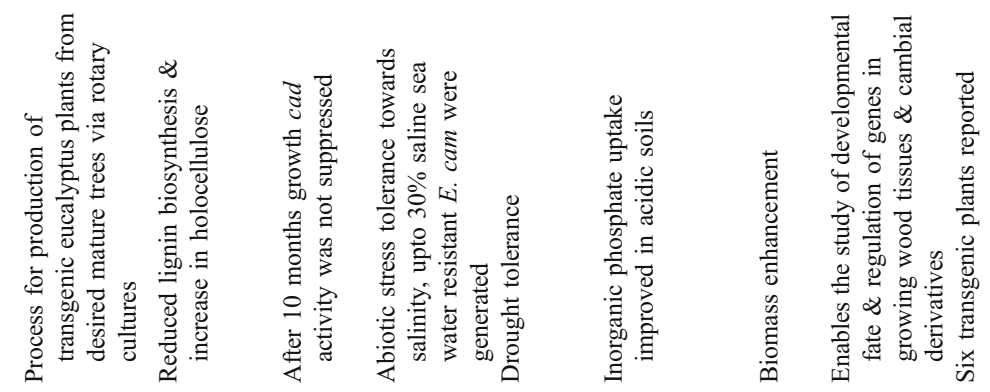

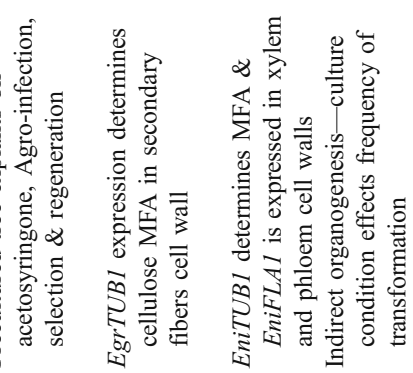

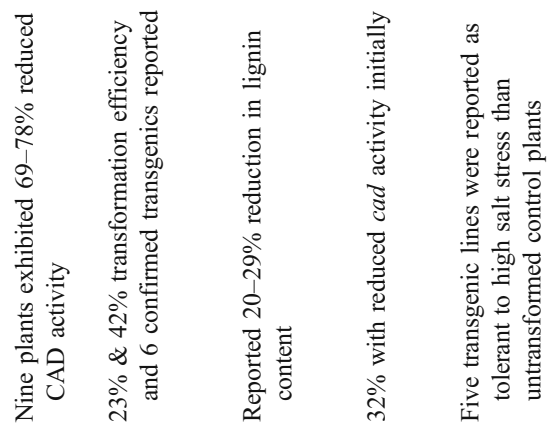
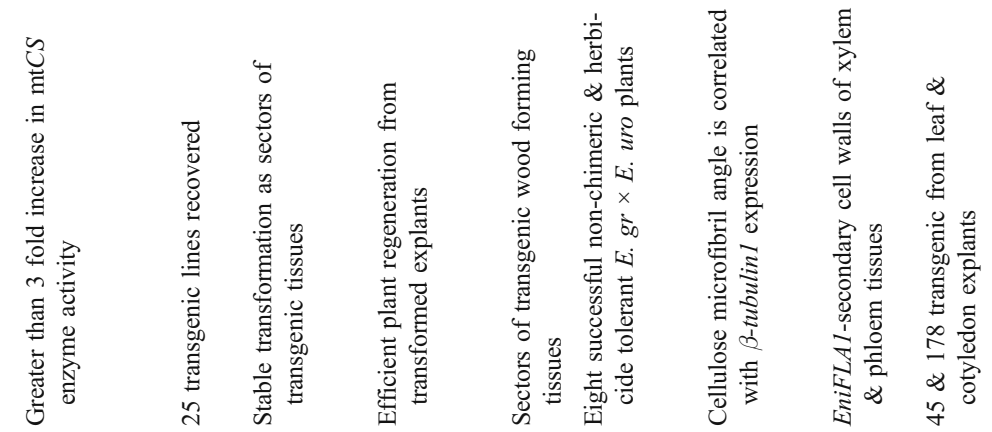

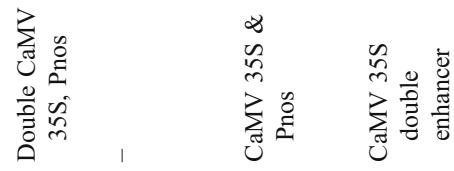

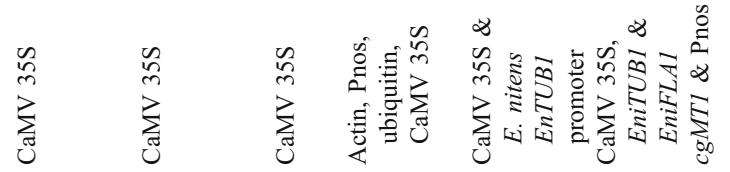

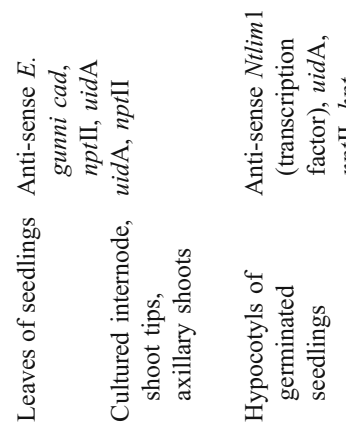

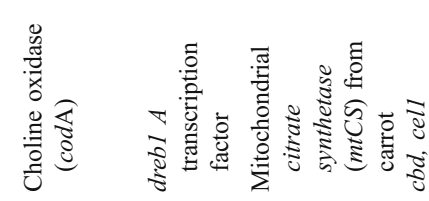

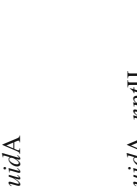

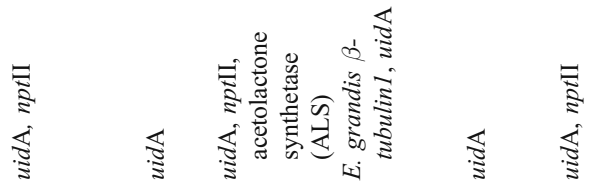
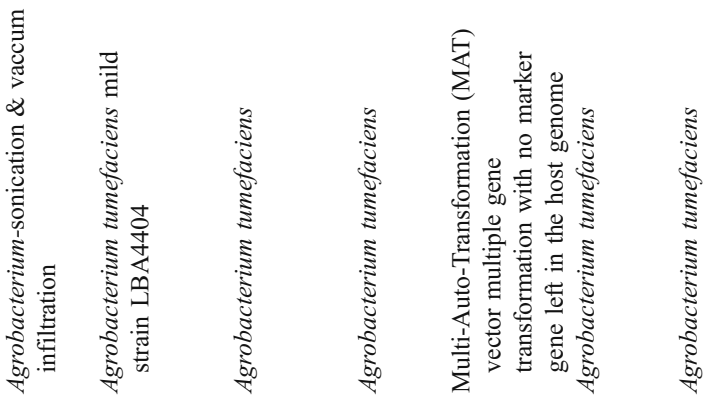

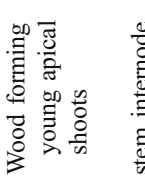

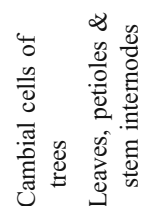

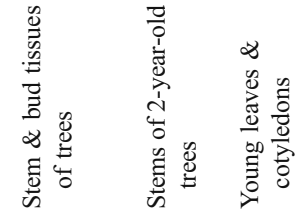

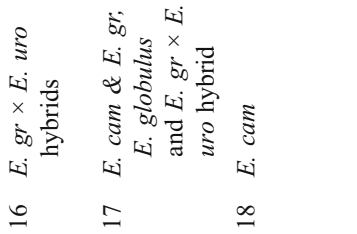

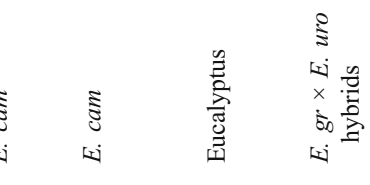
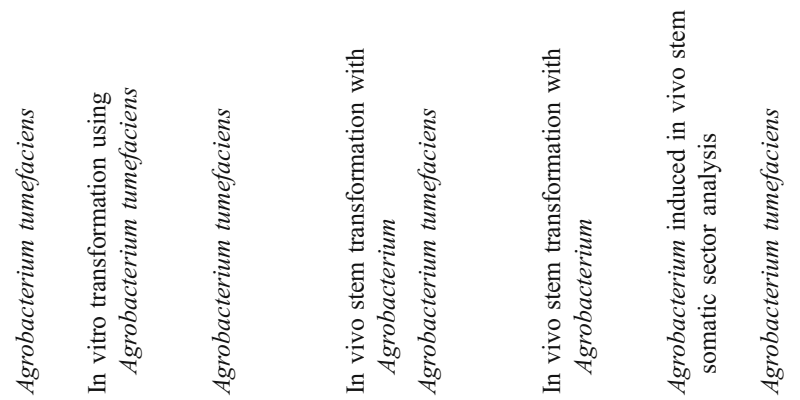

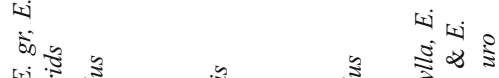


universal use of CaMV 35S promoter for genetic transformation studies.

To overcome such problems, tissue specific and inducible promoters provide the alternative means (for vector design and construction). The cell and tissue-specific expression pattern of $E g C A D 2$ promoter (a lignin biosynthetic gene) isolated from E. gunni is analyzed in a heterologus genome namely poplar. The $E g C A D 2$ promoter can be viewed from biotechnological perspective as a good candidate to target transgene expression in vascular tissues, unlike the use of constitutive promoters. This vascular specific promoter is also wound-inducible as revealed from the studies on both transgenic poplar and tobacco. Thus, this particular promoter can be used to drive the expression of defense related genes in order to enhance resistance against vascular pathogens. Further, the delineation of the cis elements required for vascular expression of EgCAD2 promoter allows transgene expression to be targeted at selected tissues and will therefore be invaluable in genetic engineering programs aimed at modifying lignin profiles (Lauvergeat et al. 2002).

In poplar protoplast transformation experiments, the CAD promoter was shown to be twice as efficient as the 35S promoter (Feuillet et al. 1995). Serrano et al. (1996), using biolistic approach transformed E. globulus for the first time with CAD promoter isolated from eucalyptus and studied GUS gene expression. Promoter comparison studies with two tissue specific promoters obtained from E. nitens namely EniPTUB1 and EniP$F L A 1$, known to play role during tension wood formation, was carried out by Taylor et al. (2007). Using these promoters they studied tissue specific GUS expression in E. globulus and Pinus alba. The results from transgenic $P$. alba indicated that EniPTUB1 is associated with secondary cell wall deposition which is inline with the EgrTUB genes role in MFA determination. On the other hand, EniPFLA1 promoter expression is found to be specific to secondary cell wall deposition especially in xylem and phloem tissues. It is observed that the number of transformed sectors observed for the two promoters was greatly reduced compared to the constitutively active CaMV $35 \mathrm{~S}$ promoter with similar patterns of GUS expression for the three promoters.

Eucalyptus EniTUB1 promoter activity was evident during xylogenesis in developing wood of transgenic tobacco plants. Further, little to no GUS activity is observed in the cambium and adjacent cells, indicating that EniTUB1 expression is limited to latter stages of xylem differentiation that include the deposition of the S2 secondary cell wall (Spokevicius et al. 2007a). Thus, a total of four tissue specific genes or their promoters have been functional characterized. These four regulatory sequences namely, EgCAD2, EgrTUB, EniTUB1 and EniFLA1 can be used 
for direct stress related genes as well as alter lignin, MFA or cellulose content via genetic transformation of eucalyptus.

Other successful heterogeneous inducible promoters used in the eucalyptus transformation studies are $c g M T I$ and petE. Quisen (2007) evaluated the suitability of $c g M T I$ promoter isolated from Casuarina glauca Metallothionein gene and transformed primordial leaves and cotyledonary explants of E. camadulensis using Agrobacterium tumefaciens co-cultivation approach. This promoter is useful in transformation works aimed at phyto-remediation of soils degraded or polluted due to heavy metal deposition. Further, a tissue specific promoter from the Pea plastocyanin gene (petE) involved in photosynthesis was used to direct the expression of the Bacillus thuringiensis cry $3 \mathrm{~A}$ gene in green-chloroplast containing cells of E. camaldulensis (Harcourt et al. 2000). Since expanding young leaves are the parts commonly attacked by defoliating insects, petE promoter forms the appropriate regulatory sequence to guide the candidate gene expression in young leaves. Identification and assessment of such promoters can pave the way to manipulate transgene expression in the desired developmental stages and plant parts.

\section{Reporter genes and selection markers}

A reporter gene helps in detection of the transformed cells. Reporter expression analysis is used to determine suitable method of transformation, transformation efficiency, promoter strength, transgene expression and tissue specificity. In eucalyptus, with few exceptions, the uidA gene coding for the enzyme $\beta$-glucuronidase (GUS) was universally used as a reporter gene. Unfortunately, uidA gene relies on histochemical staining that demands destructive sampling. Though other reporter genes are available, at least to our knowledge, none of them has been used to transform eucalyptus. This is a clear evidence for the slow pace of advancement in the field of eucalyptus transformation.

In induced somatic sector analysis (ISSA), GUS reporter system used to visualize transgenic tissue sectors, demands the destruction of the sample, making the characterization of transgene expression difficult. On the other hand, the use of non-destructive reporter systems can enable us to overcome this problem (Spokevicius et al. 2006). Sartoretto et al. (2002) reported that the GUS-expressing transgenic eucalyptus callus couldn't regenerate into transgenic shoots. Real time reports such as Green Fluorescent Protein $(g f p)$, Cyan Fluorescent Protein $(c f p)$ and Yellow Fluorescent Protein $(y f p)$ have recently been modified to contain peroxisome targeting signal peptides leading to successful application in woody perennials (Nowak et al. 2004).

The expression of selection marker in transformed cells allows its survival in selection medium. For selecting the transformed explants, generally herbicides or antibiotics are added to the tissue culture medium. Mostly in eucalyptus transformation, antibiotic kanamycin resistant nptII gene coding for neomycin phosphotransferase-II or bar gene from Streptomyces hygroscopicus - tolerant to ammonium glufosinate herbicide were used (Table 1). Other selection genes used for eucalyptus transformation studies are acetolactone synthetase (ALS) and cat. Simultaneously, transgenic eucalyptus resistant to herbicide could make the control of weeds in plantations easier and economical, particularly during the seedling establishment stage when young trees are most vulnerable to competition from weeds (Harcourt et al. 2000).

\section{Type of explants}

Explant is a plant cell or tissue that is used as a target for genetic transformation. Different types of explants are used in the in vitro and in vivo transformation studies on eucalyptus plants. They include protoplasts, zygotic embryos, young seedlings, cotyledons, hypocotyls, nodal stem segments of mature trees, leaves from in vitro germinated seedlings, in vivo wood-producing stem segments in eucalyptus. Transformation and plant regeneration of eucalyptus is generally more efficient with juvenile materials, such as hypocotyls, cotyledons and leaf discs (from in vitro grown seedlings). On the contrary, clonally derived materials from field grown trees have poor regenerating ability in tissue culture because of less percent availability of meristematic tissues (Teulieres et al. 1994; Macrae and Van Staden 1999).

Chen et al. (2001) demonstrated the advancement of gene transfer technology for E. camaldulensis from using juvenile tissues to the use of clonal tissues of mature elite trees. Generally, the nodal segments from desirable mature trees are cultured under in vitro conditions so as to generate young juvenile tissues which are the future targets for genetic transformation methods. Apart from generating transgenic eucalyptus plants, different explants are used to study the role of promoters and genes involved in wood formation. They include in vitro transformation of apical stem segments (Spokevicius et al. 2005), in vivo transformation of exposed cambial cells within mature stems (Spokevicius et al. 2006; Van Beveren et al. 2006) and in vivo transformation of developing stems after wounding of dormant lateral buds (Spokevicius et al. 2006).

\section{Methods of transformation}

Various methods for delivering foreign DNA into eucalyptus have been studied. They include electroporation, biolistics, Agrobacterium-mediate and in vivo mature stem 
transformations approaches. Initially, transformation of $E$. saligna using electroporation has been reported by Kawasu et al. (1990). Further, cat and gus gene transient expression has been studied in the protoplasts of Eucalyptus gunni and E. citriodera obtained via electroporation \pm polyethylene glycol (PEG) treatment (Teulieres et al. 1991; Manders et al. 1992). Unlike cereals, even though eucalyptus plants are known to be recalcitrant to genetic transformation, biolistic transformation was less preferred.

The first attempt on optimization of biological and physical parameters for particle bombardment in E. globulus was carried by Rochange et al. (1995). Based on transient gus expression studies, they observed that both gun powder and compressed-helium gas device exhibited similar transformation efficiency and reported that 6-dayold cultured embryos are best suited for genetic transformation of eucalyptus. Later, Serrano et al. (1996) for the first time reported successful regeneration of a single $E$. globulus plant following biolistic transformation of zygotic embryos. Biolistic transformation was also carried on hypocotyls and cotyledons of E. grandis $\times E$. urophylla hybrids (Sartoretto et al. 2002). However, this report sheds light on the shortcomings associated with biolistic transformation approach. They reported that GUS-expressing calli couldn't regenerate into transgenic shoots and that the tissue culture conditions favorable for in vitro regeneration hinders the regeneration of transgenic tissues and vice versa. It is of concern that researchers have neglected the benefits of biolistic transformation method. Performing particle bombardment of desired explants with low concentrations of target nucleotide sequence i.e. 25 nanogram of linear plasmid DNA per bombardment and removal of plasmid back bone using restriction enzymes can solve the drawbacks of this technique. Unfortunately, there are no reports of transformation work on eucalyptus in these lines where eucalyptus specific transformation parameters have been optimized.

So far, Agrobacterium-mediated transformation is the most followed and reported method in eucalyptus. First report of Agrobacterium-mediated transformation is on $E$. globulus and E. gunni by Chirqui et al. (1992). According to Mullins et al. (1997), this indirect gene transfer approach is preferred over biolistic procedures for long living tree species as it is known to reduce the insertion of multiple copies of the transgene, which can lead to gene silencing.

Machado et al. (1997) evaluated the susceptibility of $E$. grandis $\times E$. urophylla hybrids to twelve $A$. tumefaciens wild strains. Different degrees of virulence have been recorded using these stains, indicating the possibility of transforming eucalyptus hybrids with Agrobacterium derived vectors. The ability of Agrobacterium tumefaciens to infect eucalyptus varies across species and genotypes. Krimi et al. (2006) reported that E. occidentalis was more susceptible to this bacterium than E. camaldulensis and E. cladocalyx. Reports on Agrobacterium-mediated transformation in various eucalyptus species and hybrids are summarized in Table 1. Sonication assisted Agrobacterium transformation (SAAT) system was also employed in the production of transgenic eucalyptus from $E$. grandis $\times E$. urophylla hybrid (Gonzalez et al. 2002). The report indicated that germinated seeds and seedlings showed high percentage of transient GUS expression when sonicated for $30 \mathrm{~s}$ and presonication greatly enhanced the efficiency of transformation. The efficiency of the method was also assessed using a chimeric construct containing the Lhchl2 gene of the $28 \mathrm{kDa}$ chlorophyll $\mathrm{a} / \mathrm{b}$ binding pea protein from the LHC11 antenna. Using this construct, four stable transformants were generated and confirmed with genomic blotting.

The latest advancement in eucalyptus transformation has been reported by Gred Bossinger group from University of Melbourne. They reported Agrobacterium-mediated in vivo transformation of wood-producing stem segments in eucalyptus. Unlike the earlier three methods which leads to generation of stable transgenic plants, this procedure is more involved in generating transgenic sectors in growing eucalyptus plants. The details of their investigations are discussed below.

\section{Functional characterization of genes involved in wood formation using transgenic approach}

Analysis of functional aspects of a gene during the process of wood formation and wood quality in tree species presents challenges compared to annual weedy and crop species. This is due to their long generation and reproductive cycles coupled with heterozygosity. Further, when investigating wood properties a number of physical and biochemical limitations to microscopical and molecular experimentation are few other causes. To overcome these limitations, Kato et al. (2005) utilized transformed hairy roots with desired constructs that made the functional analysis possible within 1 to 2 months. With this system, they worked on evaluating the effectiveness and impact of promoters and genes in eucalyptus.

On the contrary, Agrobacterium-mediated in vitro transformation of wood-producing stem segments in eucalyptus can be readily deployed to introduce transgenes into growing wood-producing tissue. Using Agrobacterium-mediated methods, large numbers of independent transient transformation events can be obtained in situ within any cell type. This system holds promise towards becoming a standard for functional analysis of genes involved at various stages in the wood formation process directly in the tissue of interest and within a reasonable timeframe (Spokevicius et al. 2005). In vitro systems in general require the establishment and maintenance of tissues in aseptic conditions. This is 
technically demanding where time consuming where often low efficiency is achieved (Spokevicius et al. 2005).

Systems using eucalyptus in vitro stem segments have been developed in order to study de novo wood formation from cambial cells in culture (Leitch and Bossinger 2004). In these systems apical stem segments (ASS) or in situ main stem explants (MSE) from E. globulus have been used. Following an initial wounding response, cambial activity resumes leading to the formation of secondary tissue in timeframes of only a few months (Leitch 1999). The extent of secondary growth in explants is found to be affected by cambial age, position in the tree and seasonal conditions at the time of harvest. In ASS system, most cell types within the explants, including cambial initials were shown to be susceptible to Agrobacterium infection leading to the production of stably transformed de novo wood sectors. These systems potentially allow the direct comparison of transformed and non-transformed neighboring tissue within the same plant, under nearly identical conditions, thereby reducing the inherent variation between samples. Efficient use of these systems with Agrobacterium-mediated transformation has been proven to be difficult due to continued contamination following bacterial inoculation which is difficult to control. This results in a low recovery of stably transformed sectors and limited sector size due to the reduced growth periods (Spokevicius et al. 2005). Phenotypic characterization of candidate gene function in these systems has not been attempted, till date.

In other in vivo transformation attempt, cambial cells at various developmental stages within the growing stem are targeted for transformation. In this method, cambial cells are exposed by partial peeling of the bark and the transformation procedure involves application of Agrobacterium suspension on to the exposed cells followed by tight sealing, soon after the bark is positioned back in place. Candidate gene effects are then determined in relation to neighboring untransformed tissue. This method finds its advantages in minimizing expertise and labor on in vitro culturing techniques. As transgenic tissue sectors are produced directly in the growing stem, the functional analysis of genes can be studied during all stages of wood formation (Spokevicius et al. 2007a). The efficiency of this system has been demonstrated with experiments in eucalyptus describing the effects of a tubulin gene on MFA orientation in transgenic wood sectors (Spokevicius et al. 2006).

\section{Transgene escape}

Recent research in the US has found evidence that genetically modified crop plants can escape and establish in the wild, possibly for decades (BBC News 2010). According to a research team from University of Arkansas, that surveyed countryside in North Dakota for canola growing on roadsides, herbicide tolerant transgenes are present in $80 \%$ of the wild canola plants and few of the plants analysed contained two different transgenes, indicating that two different transgenic canola series had cross-pollinated resulting in canola resistant to both Roundup and LibertyLink (known chemically as glyphosate and glufosinate). Similar findings have been made in Canada, while in Japan, a study in 2008 found substantial amounts of transgenic rape-a close relative of canola - around the port areas where GM varieties have been imported.

Clearly, transgenes cannot be kept on leash and transgene escape is a virtual reality from transgenic plantations. It is unlikely that transgenes can be retracted once they are out of bottle (Marvier and Von Acker 2005; Chapman and Burke 2006). A typical example comes from transgenic bentgrass. Despite the necessary precautions on field evaluation of transgenic bentgrass at Oregon (USA), escaped herbicide-tolerant transgenes were found at $3.8 \mathrm{~km}$ away from control growing area (Reichman et al. 2006).

Ishii and $\mathrm{Lu}$ (2008) working on transgenic eucalyptus reported the occurrence and amplification of $n p t I I$ gene from the rhizosphere soils of three out of eight transgenic $E$. camaldulensis trees grown for their experimentation. Interestingly, this antibiotic resistance sequence is absent in the soils surrounding the control non transgenic trees. Research is underway as it is still unclear whether the DNA is in the soil, soil bacteria or due to Agrobacterium contamination which was used for transforming E. camaldulensis. This research is expected to shed light on the possibility of horizontal gene transfer arising due to genetic transformation, as very little is known regarding the transgene behavior and escape in forestry trees.

Most Eucalyptus sp. blooms twice a year, producing thousands of tiny pollen and seeds each flowering season. Further, eucalyptus pollen is hardy, have viability for many days at room temperature, tolerant to heat or immersion in water (Heslop-Harrison and Heslop-Harrison 1985) etc. These features could enable transgenic eucalyptus pollen to be viable and disperse to long distances, favoring transgene escape into related natural populations. Pollen and tiny seed can disperse long distances (many kilometers) by wind and biotic factors (especially insects) from plantations resulting in considerable gene flow to the neighboring forest tree populations (Slavov et al. 2009). This may very well happen with transgenic eucalyptus because of proven occurrence of natural interspecific hybrids in eucalyptus (Potts and Wiltshire 1997).

The strong concerns about transgene dispersal are illustrated by Petermann at the recent CBD meetings in Bonn, Germany: "The incidents of contamination (with genetic engineered agricultural crops) show that gene 
escape and GE contamination cannot be prevented once GE plants are released. This in turn suggests that the widespread planting of GE trees would over time lead to a persistent contamination of the world's native forests, with disruptive ecological consequences (Arent Fox2006). Although various strategies are known for containment of transgenes in the forest plantations, it may not be entirely possible to achieve $100 \%$ reproductive sterility to stop the escape of transgenic pollen and seed from transgenic trees (Ahuja 2009). Once the transgene escapes from plantation, it could conceivably displace the native forest tree genotypes or lead to maladaptation (White et al. 2007).

Keeping in view the earlier transgene escape experiences, comprehensive studies need to be undertaken before the GM trees are released for commercialization. Considering the present research efforts, it's quite clear that there is no adequate knowledge on the behavior or escape mechanisms of transgene at least in forestry trees. The well equipped and adaptable transgenic trees can easily establish in wild and displace the natural wild forest tree populations which are the reservoir of vast genetic variability and diversity.

\section{Conclusions}

Eucalyptus, due to its economic importance, is one of the first trees after poplar to get benefit from new biotechnological advancements. However, application of these tools is confronted with the problems of the globally low regeneration ability of the genus which eventually restricts the availability of genetic transformation procedures to few species and genotypes (Teulieres and Marque 2007). So far, the advancements made in the genetic transformation studies of eucalyptus are still in a state of infancy. The knowledge gained from plant genomics from other tree species and model plants has a long way to go in the development of this hardwood tree in order to obtain plants with desired traits for commercial utilization.

Use of tissue specific or inducible promoters in gene constructs will be more relevant especially in the case of eucalyptus where wood yield and quality are of main concern. However, promoter selection is especially difficult for trees where complex developmental phases occur with increasing size and tissue complexity across years, making it difficult to comprehensively study a given promoter sequence. An example for this complexity is that the floral tissue specific genes in poplar also show some degree of vegetative expression and this can vary widely in intensity across the annual cycle of growth alterations encompassed with biotic and abiotic stresses across their lengthy life cycles. Therefore, promoter fidelity and stability of transgene expression have to be viewed at several different levels across space and time in the long-lived forest trees like eucalyptus.

Recent findings by Spokevicius et al. (2007b) regarding decrease in EgrTUB1 expression in transgenic wood sectors of E. globulus brings out the very fact of homologydependent gene silencing (HDGS). This type of silencing in plants is triggered by high sequence homology between exogenous against endogenous gene sequences, leading to decrease in the expression of both homologues. On the contrary, the very same construct could over-expressed in wood sectors of Pinus alba, thus proving the fact that gene from the same genus when transformed back into the parent genome can lead to transgene silencing because of sequence repetition or homology.

Eucalyptus tree has lengthy life cycle which in turn affects the generation and selection of marker free transgenic plants. In such situations, lessons from the recent work by $\mathrm{Lu}$ et al. (2009) from University of Missouri, dealing with the development of marker-free transgenic sorghum plants using Agrobacterium co-cultivation strategy, should be helpful for eucalyptus researchers and can be tried in future. Lu et al. (2009) used separate binary vectors containing bar and target gene and co-transformed immature embryo derived callus. Using mild selection pressure (in order not to lose the transformed cells) in $\mathrm{T}_{0}$ generation they could finally obtain progeny plants harboring the candidate gene only. Thus, they could eliminate the progeny sorghum plants having marker gene co-segregating along with the candidate gene of interest. This line of research could lead the future eucalyptus transformation attempts towards a fruitful result. Generation and screening of more number of transgenic events should be the prime focus in order to meet the goal of transformation. Except for few occasions, most of the earlier transformation reports on eucalyptus did not meet these requirements. Instead of working for transformation successes in just few events, the researchers should focus their efforts towards generating multiple events having successful insertion of the transgene into eucalyptus genome. This can form the platform for the remaining segregation and bioassay studies that can eventually lead towards the successful release of transgenic eucalyptus.

Over expression of transgenes in eucalyptus was known to have detrimental effect on the morphology and growth of the tree while lower expression levels may not serve the purpose of intent. Use of mild Agrobacterium strains for cocultivation (like LBA4404) instead of hypervirulant strains (such as C58 derivatives) can result in the development of transgenic plants with single or lower copies of the candidate gene. Further, necessary measures to reduce transgene silencing phenomenon due to positional effect can be avoided by flanking the transgene on either side with Matrix Attachment Regions (MARs elements, if necessary). It is important to note that by allowing the explants to spend less 
time in tissue culture regeneration medium i.e. following direct embryogenesis or organogenesis pathways, the occurrence of somaclones and chimeras can be minimized. Studies on transgene expression and behavior in transgenic eucalyptus trees is still at preliminary stages because of multiple growth phases that vary with time and space; hinders the study of complete transgene expression. Transgene escape into natural environment could be a constant threat in the case of eucalyptus because of its hardy and viable pollen, lengthy life cycle, perennial nature, large biomass, long flowering seasons, entomophilous pollination and tiny seeds.

\section{References}

Ahuja MR (2009) Transgene stability and dispersal in forest trees. Trees 23:1125-1135

Arent Fox (2006). International Environment Resources: Biosafety Regulation Sourcebook. (Available at www.arentfox.com/model biosafetyact.pdf)

Bandyopadhyay S, Cane K, Rasmussen G, Hamill JD (1999) Efficient plant regeneration from seedling explants of two commercially important temperate eucalyptus species-Eucalyptus nitens and E. globulus. Plant Sci 140(2):189-198

BBC news (2010) http://www.bbc.co.uk/news/science-environment10859264 dated 6 August, 2010

Chapman MA, Burke JM (2006) Letting the gene out of the bottle: populations genetics of genetically modified crops. New Phytology 170:429-443

Chen Z, Tsay J, Chung J (1996) Callus culture of Eucalyptus grandis $\times$ E. urophylla and preliminary studies on organogenesis and Agrobacterium transformation. Taiwan J For Sci 11(1):43-52

Chen Z, Chang S, Ho C, Chen Y, Tsai J, Chiang V (2001) Plant production of transgenic Eucalyptus camaldulensis carrying the Populus tremulö̈des cinnammate 4-hydroxylase gene. Taiwan J For Sci 16:249-258

Cheng (2006) Eucalyptus urophylla transformation and selection. Patent: US20060101537 A1, May 11, 2006

Chiang VL, Puumala RJ, TakeuchI H, Eckert RE (1988) Comparison of softwood and hardwood kraft pulping. Tappi J 71:173-176

Chriqui D, Adam S, Caissard JC, Noin M, Azim A (1992) Shoot regeneration and Agrobacterium-mediated transformation of $E$. globulus and E. gunni. In Schonau APG (editor) IUFRO symposium on intensive forestry: the role of Eucalyptus. Proceedings. Pretoria, South Africa: South African Institute of Forestry 70-80

Dibax R, Deschamps C, Bespalhok Filho JC, Vieira E, Molinari C, Campos D, Quoirin M (2010) Organogenesis and Agrobacterium tumefaciens-mediated transformation of Eucalyptus saligna with P5CS gene. Biol Plant 54(1):6-12

Eldridge K, Davidson C, Harwood C, Van Wyk G (1994) Eucalyptus domestication and breeding. Oxford University Press, New York

Feuillet C, Lauvergeat V, Deswarte C, Pilate G, Boudet A, GrimaPettenati J (1995) Tissue-specific and cell-specific expression of a cinnamyl alcoholdehydrogenase promoter in transgenic poplar plants. Plant Mol Biol 27:651-667

GIT Forestry (2008) Cultivated eucalyptus global map 2008. http:// www.git-forestry.com

Girijashankar V, Swathisree V (2009) Genetic Transformation of Sorghum bicolor. Physiol Mol Biol Plants 15(4):1-16

Gonzalez ER, Andrade A, Bertolo L, Lacerda G, Carneiro R, Defavari V, Labate M, Labate C (2002) Production of transgenic Eucalyptus grandis $\times$ E. urophylla using the sonication-assisted
Agrobacterium transformation (SAAT) system. Funct Plant Biol 29(1):97-102

Harcourt RL, Kyozuka J, Floyd RB, Bateman KS, Tanaka H, Decroocq V, Llewellyn DJ, Zhu X, Peacock WJ, Dennis ES (2000) Insect- and herbicide-resistant transgenic eucalyptus. Mol Breed 6:307-315

Heslop-Harrison J, Heslop-Harrison Y (1985) Germination of stress tolerant eucalyptus pollen. J Cell Sci 73:135-157

Higuchi T (1990) Lignin biochemistry: biosynthesis and biodegradation. Wood Sci Technol 24:23-63

Ho CK, Chang SH, Tsay JY, Tsai CJ, Chiang VL, Chen ZZ (1998) Agrobacterium tumefaciens-mediated transformation of Eucalyptus camaldulensis and production of transgenic plants. Plant Cell Rep 17:675-680

Ishige N, Kondo K, Furujyo A, Hibino T (2004) Genetic improvement for environmental stress resistance in eucalyptus. In: Proc Plant and Animal Genome 12th Conf, San Diego, California, 10-14 January, http://www.intl-pag.org/12/abstracts

Ishii K, Lu MZ (2008) Testing the possibility of horizontal transfer of introduced neomycin phosphotransferase (nptII) gene of transgenic Eucalyptus camaldulensis into soil bacteria. For Studies China 10(2):134-136

ISIS (2010) http://www.i-sis.org.uk/FTGEEEASI.php

Kato T, Kihara T, Kimoto M, Kitamura T, Kawazu T (2005) Analysis of modified root function of eucalyptus with hairy roots. Supplement to Plant Cell Physiol 48:973-973

Kawaoka A, Nanto K, Sugita K, Endo S, Yamada-Watanabe K, Matsunaga E, Ebinuma H (2003) Production and analysis lignin modified transgenic eucalyptus. In: Sundberg B (ed) IUFRO tree biotechnology. Umea Plant Science Center, Umea, pp S10-S16

Kawaoka A, Nanto K, Ishii K, Ebinuma H (2006) Reduction of lignin content by suppression of expression of the LIM domain transcription factor in Eucalyptus camaldulensis. Silvae Genet 55(6):269-277

Kawasu T, Doi K, Ohta T, Shinohara Y, Ito K, Shibata M (1990) Transformation of Eucalyptus saligna using electroporation. Abstract In: 7th international congress on plant tissue and cell culture, Amsterdam. IAPTC 24-29, June, pp 64

Kawasu T, Susuki Y, Wada T, Kondo K, Koyama H (2003) Over expression of a plant mitochondrial citrate synthase in eucalyptus trees improved growth when cultured by alphosphate as a sole phosphate source. Plant Cell Physiol 44:S91

Kawazu T (2003) Process for transformation of mature trees of eucalyptus plants. Patent US 6563024. May 13, 2003

Kondo K, Furuyjyo A, Ishigi N, Kasuga M, Shinozaki K, YamaguchiShinozaki K, Hibino T (2003) Analysis of the stress response genes in eucalyptus and effect of introducing several stress tolerance-giving genes into eucalyptus; A development situation and a practical possibility of an environmental stress resistant tree. In: Proc Plant and Animal Genome 11th conf San Diego California, http://www.intl-pag.org/11/p7b-p826-xi.html

Krimi Z, Raio A, Petit A, Nesme X, Dessaux Y (2006) Eucalyptus occidentalis plantlets are naturally infected by pathogenic Agrobacterium tumefaciens. Eur J Plant Pathol 116:237-246

Lapierre C, Pollet B, Petit-Conil M, Toval G, Romero J, Pilate G, Leplé JC, Boerjan W, Ferret V, De Nadai V, Jouanin L (1999) Structural alterations of lignins in transgenic poplars with depressed cinnamyl alcohol dehydrogenase or caffeic acid Omethyltransferase activity have opposite impact on the efficiency of industrial Kraft pulping. Plant Physiol 119:153-163

Lauvergeat V, Rech P, Jauneau A, Guez C, Coutos-Thevenot P, Grima-Pettenati J (2002) The vascular expression pattern directed by the Eucalyptus gunnii cinnamyl alcohol dehydrogenase EgCAD2 promoter is conserved among woody and herbaceous plant species. Plant Mol Biol 50:497-509 
Leitch MA (1999) The development of tissue culture techniques to study wood formation in Eucalyptus globulus Labill, $\mathrm{PhD}$ Thesis) University of Melbourne, Australia

Leitch MA, Bossinger G (2004) In vitro systems for the study of wood formation. In: Kumar S, Fladung M (eds) Molecular genetics and breeding of forest trees. Haworth, New York, pp 193-211

Long JM, Conn AB, Batchelor WJ, Evans R (2000) Comparison of methods to measure fibril angle in wood fibres. Appita J 53:206-209

Lu L, Xingrong W, Xiaoyan Y, Jonathan M, Chen X, Folk WR, Zhang ZJ (2009) Development of marker-free transgenic sorghum [Sorghum bicolor (L.) Moench] using standard binary vectors with bar as a selectable marker. Plant Cell Tissue Organ Cult 99:97-108

Machado R, Andrade D, Cid B, Penchel RM, Brasileiro M (1997) Agrobacterium strain specificity and shooty tumour formation in eucalyptus (Eucalyptus grandis $\times$ E. urophylla). Pl Cell Rep 16:299-303

Macmillan CP, Mansfield SD, Stachurski ZH, Evans R, Southerton SG (2010) Fasciclin-like arabinogalactan proteins: specialization for stem biomechanics and cell wall architecture in Arabidopsis and eucalyptus. Plant J 62(4):689-703

Macrae S, Van Staden J (1993) Agrobacterium rhizogenes-mediated transformation to improve rooting ability of eucalyptus. Tree Physiol 12:411-418

Macrae S, Van Staden J (1999) Transgenic eucalyptus. In: Bajaj YPS (ed) Biotechnology in agriculture and forestry. Heidelberg, Springer. 44:88-114

Manders G, Santos D, Utra Vaz FB, Davey MR, Power JB (1992) Transient gene expression in electroporated protoplasts of Eucalyptus citriodora Hook. Plant Cell Tissue Organ Cult 30:69-75

Marvier M, Von Acker RC (2005) Can crop transgenes be kept on a leash? Front Ecol Environ 3:99-106

Monties B (1989). Lignins. In: Dey PM, Harborne JB (eds) Methods in plant biochemistry: Pl Phenolics. Academic, New York. $1: 113-157$

Moralejo M, Rochange F, Boudet AM, Teulieres C (1998) Generation of transgenic Eucalyptus globulus plantlets through Agrobactrium tumefaciens mediated transformation. Aust J Plant Physiol 25(2):207-212

Mullins KV, Llewellyn DJ, Hartney VJ, Strauss S, Dennis ES (1997) Regeneration and transformation of Eucalyptus camaldulensis. Plant Cell Rep 16:787-791

Navarro M, Celine A, Yves M, Joan L, Walid EK, Christiane M, Teulières C (2010) Two EguCBF1 genes over expressed in eucalyptus display a different impact on stress tolerance and plant development (p). Plant Biotech J. Published Online: 17 May 2010. doi:10.1111/j.1467-7652.2010.00530.x

Nowak K, Luniak N, Meyer S, Schulze J, Mendel RR, Hansch R (2004) Fluorescent proteins in poplar: a useful tool to study promoter function and protein localization. Plant Biol 6:65-73

Potts BM, Wiltshire RJE (1997) Eucalyptus genetics and genecology. In: Williams J, Woinarski J (eds) Eucalypt ecology: individuals to ecosystems. Cambridge University Press, Cambridge, pp 5691

Prakash MG, Gurumurthi K (2009) Genetic transformation and regeneration of transgenic plants from precultured cotyledon and hypocotyl explants of Eucalyptus tereticornis Sm. using Agrobacterium tumefaciens. In vitro Cell Dev Biol Plant 45 (4):429-434

Quisen RC (2007) Transformacao genetica De Eucalyptus camaldulensis via co-cultivo com Agrobacterium tumefaciens. ( $\mathrm{PhD}$ Thesis) Agronomical Sciences, Federal University of Parana, Curitiba, Brazil

Quoirin M, Quisen R (2006) Advances in genetic transformation of Eucalyptus species. In: Franche C (eds) Mol Biol Trop Pl. Research Signpost, Kerala, pp 41-56
Reichman JR, Watrud LS, Lee EH, Burdick CA, Bollman MA, Strom MJ, King GA, Mallory-Smith C (2006) Establishment of transgenic herbicide resistant creeping bentgrass (Agrostis stolonifera L.) in non-agronomic habitats. Mol Ecol 15:4243-4255

Rochange F, Serrano L, Marque C, Teulieres C, Boudet AM (1995) DNA delivery into Eucalyptus globulus zygotic embryos through biolistics: optimization of the biological and physical parameters of bombardment for two different particle guns. Plant Cell Rep 14:674-678

Sartoretto LM, Barrueto CLP, Brasileiro ACM (2002) Biolistic transformation of Eucalyptus grandis $\times$ E. urophylla callus. Funct Plant Biol 29:917-924

Savidge RA (2000) Biochemistry of seasonal cambial growth and wood formation - an overview of the challenges. In: Savidge RA, Barnett JR, Napier R (eds) Cell and molecular biology of wood formation. BIOS Scientific Publishers, Oxford, pp 1-28

Serrano L, Rochange F, Semblat JP, Marque C, Teulieres C, Boudet AM (1996) Genetic transformation of Eucalyptus globulus through biolistics: complementary development of procedures for organogenisis from zygotic embryos and stable transformation of corresponding proliferating tissue. J Exp Bot 47:285-290

Shani Z, Dekel M, Cohen B, Barimboim N, Kolosovski N, Safranuvitch A, Cohen O, Shoseyov O (2003) Cell wall modification for the enhancement of commercial eucalyptus species. In: Sundberg B (ed) IUFRO tree biotechnology. Umea Plant Science Center, Umea, pp S10-S26

Shani Z, Dekel M, Cohen B, Barimboim N, Cohen O, Halay T, Kolosovski N, Shoseyov O (2004) Eucalyptus in the changing world. In: Borralho $\mathrm{N}$ (eds) Proceedings of the International IUFRO conference. Aveiro, Portugal, p 668

Shao Z, Chen W, Luo H, Ye X, Zhan J (2002) Studies on the introduction of cecropin D gene into Eucalyptus urophylla to breed the resistant varieties to Pseudomonas solaniacearum. Sci Silvae Sin 38:92-97

Slavov GT, Leonardi S, Burczyk J, Adams WT, Strauss SH, Difazio SP (2009) Extensive pollen flow in two ecologically contrasting populations of Populus trichocarpa. Mol Ecol 18:357-373

Sonoda T, Koita H, Nakamoto-Ohta S, Kondo K, Suezaki T, Kato T, Ishizaki $Y$, Nagai $K$, Iida $N$, Sato $S$, Umezawa $T$, Hibino $T$ (2009) Increasing fiber length and growth in transgenic tobacco plants overexpressing a gene encoding the Eucalyptus camaldulensis HD-Zip class II transcription factor. Plant Biotech 26:115120

Spokevicius AV, Van Beveren K, Leitch MA, Bossinger G (2005) Agrobacterium-mediated in vitro transformation of woodproducing stem segments in eucalypts. Plant Cell Rep 23:617624

Spokevicius AV, Van Beveren K, Bossinger G (2006) Agrobacteriummediated transformation of dormant lateral buds in poplar trees reveals developmental patterns in secondary stem tissues. Funct Plant Biol 33:133-139

Spokevicius AV, Southerton SG, Mac Millan CP, Qiu D, Gan S, Tibbits JFG, Moran GF, Bossinger G (2007a) $\beta$-tubulin affects cellulose microfibril orientation in plant secondary fibre cell walls. Plant J 51:717-726

Spokevicius AV, Tibbits JFG, Bossinger G (2007b) Whole plant and plant part transgenic approaches in the study of wood formation-benefits and limitations. Global Science Books. Trans Plant J 1:49-59

Suzuki Y, Kawazu T, Tsuyama M, Wada T, Kondo K, Mizuno R, Hara T, Koyama H (2004) Characteristics of transgenic eucalyptus hybrids with an overexpression of a plant mitochondrial citrate synthase. Nippon Shokubutsu Seiri Gakkai Nenkai oyobi Shinpojiumu Koen Yoshishu 45:07

Taylor LR, Spokevicius AV, Mac Millan CP, Southerton SG, Bossinger G (2007) Promoter studies during tension wood formation using 
induced somatic sector analysis (ISSA). Poster presented at IUFRO Tree Biotechnology Congress

Teulieres C, Marque C (2007) Eucalyptus. In: Pua EC, Davey MR (eds) Biotechnology in agriculture and forestry 60, Transgenic Crops V. Springer, New York, pp 387-402

Teulieres C, Grima Pettenati J, Curie C, Teissie J, Boudet AM (1991) Transient foreign gene expression in polyethylene/glycol treated or electropulsated Eucalyptus gunnii protoplasts. Plant Cell Tissue Organ Cult 25:125-132

Teulieres C, Marque C, Boude AM (1994) Genetic transformation of eucalyptus. In: Bajaj YPS (ed) Biotechnology in agriculture and forestry V, plant protoplasts and genetic engineering. Springer, Berlin, Heidelberg, New York 29:289-307

Thumma BR, Nolan MR, Evans R, Moran GF (2005) Polymorphisms in cinnamoyl CoA reductase (CCR) are associated with variation in microfibril angle in Eucalyptus sp. Genetics 171:1257-1265

Tournier V, Grat S, Marque C, El Kayal W, Penchel R, Andrade DG, Boudet AM, Teulieres C (2003) An efficient procedure to stably introduce genes into an economically important pulp tree (Eucalyptus grandis $\times$ Eucalyptus urophylla). Trans Res 12:403-411

Vain P (2006) Global trends in plant transgenics. Science and Technology (1973-2003). Trends Biotech 24:206-211

Valerio L, Carter D, Rodrigues JC, Tourier V, Gominho J, Marque C, Boudet AM, Maunders M, Pereira H, Teulieres C (2003)
Down regulation of cinnamyl alcohol dehydrogenase, a lignification enzyme, in Eucalyptus camaldulensis. Mol Breed 12:157-167

Van Beveren K, Spokevicius AV, Tibbits J, Wang Q, Bossinger G (2006) Transformation of cambial tissue in vivo provides efficient means for Induced Somatic Sector Analysis (ISSA) and gene testing in stems of woody plants species. Funct Plant Biol 33:629-638

White TL, Adams WT, Neale DB (2007) Forest genetics. CABI Publication, Cambridge

Yahiaoui N, Marque C, Corbiere H, Boudet AM (1998) Comparative efficiency of different constructs for down regulation of tobacco cinnamyl alcohol dehydrogenase. Phytochemistry 49:295-305

Yamada-Watanabe K, Kawaoka A, Matsunaga K, Nanto K, Sugita K, Endo S, Ebinuma H, Murata N (2003) Molecular breeding of Eucalyptus: analysis of salt stress tolerance in transgenic Eucalyptus camaldulensis that over-expressed choline oxidase gene $(\operatorname{cod} A)$. In: Sundberg B (ed) IUFRO tree biotechnology. Umea Plant Science Centre, Umea, pp S7-S9

Yao JL (2005) Eucalyptus transformation method. Patent: US 2005/ 0086714 A1. April, 21, 2005

Zhong RQ, Burk DH, Morrison WH, Ye ZH (2002) A kinesin-like protein is essential for oriented deposition of cellulose microfibrils and cell wall strength. Plant Cell 14:3101-3117 